\title{
Correction to: Reduced level of physical activity during COVID-19 pandemic is associated with depression and anxiety levels: an internet-based survey
}

Paulo José Puccinelli ${ }^{1}$, Taline Santos da Costa ${ }^{1}$, Aldo Seffrin ${ }^{1}$, Claudio Andre Barbosa de Lira², Rodrigo Luiz Vancini ${ }^{3}$, Pantelis T. Nikolaidis ${ }^{4}$, Beat Knechtle ${ }^{5,6}$, Thomas Rosemann ${ }^{6}$, Lee Hill ${ }^{7}$ and Marilia Santos Andrade ${ }^{1 *}$

\section{Correction to: BMC Public Health (2021) 21:425 https://doi.org/10.1186/s12889-021-10470-z}

It was highlighted that in the original article [1], in the first sentence of the Results section of the Abstract, the numbers were interchanged. This Correction article shows the incorrect and correct sentence in the Results section of the Abstract. The original article has been updated.

\section{Incorrect sentence}

Results: The physical activity level adopted during the period of social distancing $(3.5 \pm 0.8)$ was lower than that the adopted prior to the pandemic period $(2.9 \pm 1.1$, $p<0.001$ ).

\section{Correct sentence}

Results: The physical activity level adopted during the period of social distancing $(2.9 \pm 1.1)$ was lower than that adopted prior to the pandemic period $(3.5 \pm 0.8$, $p<0.001)$.

\footnotetext{
Author details

'Department of Physiology, Federal University of São Paulo, São Paulo, Brazil. ${ }^{2}$ Human and Exercise Physiology Division, Faculty of Physical Education and Dance, Federal University of Goiás, Goiânia, Brazil. ${ }^{3}$ Center for Physical Education and Sports, Federal University of Espírito Santo, Victoria, Brazil. ${ }^{4}$ School of Health and Caring Sciences, University of West Attica, Athens, Greece. ${ }^{5}$ Medbase St. Gallen Am Vadianplatz, St. Gallen, Switzerland. ${ }^{6}$ Institute of Primary Care, University of Zurich, Zurich, Switzerland. ${ }^{7}$ Divison of
}

The original article can be found online at https://doi.org/10.1186/s12889021-10470-z

* Correspondence: marilia1707@gmail.com

'Department of Physiology, Federal University of São Paulo, São Paulo, Brazil Full list of author information is available at the end of the article
Gastroenterology and Nutrition, Department of Pediatrics, McMaster University, Hamilton, Canada.

Published online: 29 March 2021

\section{Reference}

1. Puccinelli PJ, et al. Reduced level of physical activity during COVID-19 pandemic is associated with depression and anxiety levels: an internetbased survey. BMC Public Health. 2021;21:425. https://doi.org/10.1186/s12 889-021-10470-z.

(c) The Author(s). 2021 Open Access This article is licensed under a Creative Commons Attribution 4.0 International License, which permits use, sharing, adaptation, distribution and reproduction in any medium or format, as long as you give appropriate credit to the original author(s) and the source, provide a link to the Creative Commons licence, and indicate if changes were made. The images or other third party material in this article are included in the article's Creative Commons licence, unless indicated otherwise in a credit line to the material. If material is not included in the article's Creative Commons licence and your intended use is not permitted by statutory regulation or exceeds the permitted use, you will need to obtain permission directly from the copyright holder. To view a copy of this licence, visit http://creativecommons.org/licenses/by/4.0/ The Creative Commons Public Domain Dedication waiver (http://creativecommons.org/publicdomain/zero/1.0/) applies to the data made available in this article, unless otherwise stated in a credit line to the data. 